\title{
Grain yield and technological quality of dual-purpose wheats with additional late nitrogen fertilization
}

\author{
Angelica Consoladora Andrade Manfron $^{1} \oplus$, Renato Serena Fontaneli $i^{1,2}$ \\ ${ }^{1}$ Universidade de Passo Fundo, Passo Fundo, RS, Brasil. E-mail: ange.angelyca@gmail.com \\ ${ }^{2}$ Embrapa Trigo, Passo Fundo, RS, Brasil. E-mail: renato.fontaneli@embrapa.br
}

ABSTRACT: The yield and grain quality of dual-purposes wheat cultivars may fluctuate due to the applied management, producing lower results than the expected. This study aimed to determine if the application of an additional dose of nitrogen, at the earing stage beginning, increases the grain yield and modifies the technological quality in double-purpose wheat, regardless of the cutting regime. The experiment was conducted in the experimental field of Embrapa Trigo, in Coxilha-RS, Brazil, 2017. Two dual-purpose wheat cultivars (BRS Tarumã and BRS Pastoreio) and three cutting regimes (no cut, one and two cuts) were used, being submitted or not the application of additional nitrogen fertilization at the beginning of the earing. A trifatorial arrangement was employed, with a randomized block design and three replicates. Data attained were submitted to analysis of variance and compared by the Tukey test at $5 \%$ of probability. The evaluated attributes were the height of the plant at harvest, yield, thousand grain weight, number of spikelets/ear, weight of the hectoliter, falling number, and protein in the grain. Additional application of nitrogen did not increase the yield for any studied genotypes, regardless of the cutting regimes, and as for grain quality, the differences between the materials should be taken into account.

Key words: dual-purpose management; late fertilization; Triticum aestivum L.

\section{Rendimento de grãos e qualidade tecnológica de trigos de duplo propósito com adubação nitrogenada tardia adicional}

RESUMO: O rendimento e qualidade de grãos de cultivares de trigo de duplo propósito podem oscilar devido ao manejo utilizado, gerando resultados inferiores ao esperado. Busca-se saber se a aplicação de dose adicional de nitrogênio, no início do espigamento, aumenta o rendimento de grãos e modifica a qualidade tecnológica em trigos duplo propósito, independente do regime de cortes. O experimento foi conduzido no campo experimental da Embrapa Trigo, em Coxilha-RS, em 2017. Sendo utilizadas duas cultivares de trigo duplo propósito (BRS Tarumã e BRS Pastoreio), três regimes de cortes (sem corte, um e dois cortes), submetidos ou não a aplicação de adubação nitrogenada adicional no início do espigamento. Foi utilizado arranjo trifatorial, com delineamento em blocos ao acaso e três repetições. Os dados obtidos foram submetidos à análise de variância e comparados pelo teste de Tukey a $5 \%$ de probabilidade. Foram avaliados a altura da planta na colheita, rendimento, massa de mil grãos, número de espiguetas/espiga, peso do hectolitro, número de queda, proteína no grão. A aplicação adicional de nitrogênio não aumentou o rendimento para nenhum dos genótipos estudados independente dos regimes de cortes e para qualidade dos grãos devem-se levar em conta as diferenças entre os materiais.

Palavras-chave: manejo de duplo propósito; fertilização tardia; Triticum aestivum L. 


\section{Introduction}

In the southern region of Brazil, the most employed croplivestock integration system involves livestock production in winter, mainly using ryegrass and oats to feed the livestock; and during summer, the production of grains such as soybeans and corn excels as the most cultivated (Martin et al., 2010).

As a way to further integrate animal and grain production, a trait from this region, which has as traditional management the use of black oats aiming only at forage production, and because it is a material not so adequate regarding food quality (Wendt et al., 2006), dual-purpose cultivars, such as wheat (Triticum Storeum L.) appear as an alternative.

Yield from dual-purpose materials, in relation to the grain yield, may fluctuate due to its management, causing some of these materials not to show satisfactory grain quality and yield, occurring a reduction after more intensive grazing cycles (Zilio et al., 2017). This said reduction leads many producers to label dual-purpose wheat as a material with low grain yield potential and low technological quality.

In the traditional management of dual-purpose wheat, nitrogen $(N)$ is applied at the sowing, tillering and after each cut, in order to the plants recover and sprout (Fontaneli et al., 2016).

Due to $\mathrm{N}$ being of great importance for wheat, considering its participation in protein synthesis and in substances that determine technological quality (Vieira et al., 1995), when applied at certain times as topdressing, it ends up being available in higher consumption periods, thus being also able to change the grain yield in materials that are not used for double-purpose (Bredemeier \& Mundstock, 2001).

$\mathrm{N}$ application at times other than the traditional, as such in the reproductive times, does not usually have differences in grain yield in relation to the absence of fertilization at this stage, but may present a higher weight of grain hectoliter (Almeida et al., 2011).

These nitrogen fertilizations, when close to flowering, may result in positive results when the wheat quality is evaluated, but has no effect on its actual yield (Garrido-Lestache et al., 2004; Sangoi et al., 2007). That is because the grain weight during its filling is the last component to be defined after the anthesis and the prior stages environmental conditions may influence it. However, elevated temperatures during grain formation may reduce its final weight and thus affect crop yield (Calderini et al., 1999).

Cuts management is another factor that can cause stress to the plants, leading to a reduction in grain yield and quality, but on the other hand, it provides food for the fattening and weight maintenance of the livestock, thus the cuts end up being needed and contributing to the integration system.

This study has as objective to verify if the application of an additional nitrogen fertilizer dose at the earing beginning increases the yield and improves the quality of dual-purpose wheat grains, regardless of the cutting regime employed.

\section{Material and Methods}

The experiment was conducted in 2017 at the experimental field from Embrapa Trigo, Coxilha-RS. It was composed of 12 treatments from a three-factor arrangement ( 2 cultivars $x 3$ cutting regimes $x 2$ additional nitrogen fertilizer managements), arranged in a randomized block design with three replicates.

Experimental units consisted of seven lines of 5 meters of length, with 0.20 meters between the rows, totaling $7 \mathrm{~m}^{2}$.

The double-purpose wheat cultivars (BRS Tarumã and BRS Pastoreio) were subjected to regimens with one, two or no cuts, also receiving or not an additional nitrogen dose at the beginning of the earing, characterized by stage 10.1, according to the scale from Feeks \& Large (Large, 1954).

Sowing of the trial was carried out in April 2017, with density of 350 suitable seeds per $\mathrm{m}^{2}$ and $300 \mathrm{~kg}$ of fertilizer from the formula 05-25-25 $\left(\mathrm{N}_{-} \mathrm{P}_{2} \mathrm{O}_{5}-\mathrm{K}_{2} \mathrm{O}\right)$, used as base fertilizer as analyzed at the sowing time. Other $\mathrm{N}$ applications were carried out as urea in the tillering stage, and after each cut the plants received $30 \mathrm{~kg}$ of $\mathrm{N} \mathrm{ha}^{-1}$.

Cuts were made when the plants reached between 25 and $30 \mathrm{~cm}$ in height, maintaining a stubble height between 7 and $10 \mathrm{~cm}$, to allow the regrowth to occur and preserving the growth point. The cutting area was done with a bar mower (Winterstiger) aiming to simulating grazing, with the cut forage being removed from the area, so that it did not cover the crop. In treatments with two cuts, the process was repeated when the regrowth of the plants reached the cutting height once again.

At the end of the crop cycle, the no cuts and the no additional application of $\mathrm{N}$ treatments did not receive any dose of $\mathrm{N}$ after application in tillering; however, where there were no cuts but there was application of additional $\mathrm{N}$, the dosage used was $30 \mathrm{~kg}$ per hectare, at the end of the cycle. One cut and no additional $\mathrm{N}$ treatment received $30 \mathrm{~kg} \mathrm{ha}^{-1} \mathrm{~N}$, one cut and additional $\mathrm{N}$ application treatment received $60 \mathrm{~kg} \mathrm{ha}^{-1} \mathrm{~N}$. Two cuts and no additional $\mathrm{N}$ application treatment received $60 \mathrm{~kg} \mathrm{ha}^{-1} \mathrm{~N}$, which went up to $90 \mathrm{~kg}$ of $\mathrm{N}$ per hectare after the later application. In all these values are already discounted the values that the plant received from $\mathrm{N}$ at base and tillering.

Three fungicide and two insecticide applications were carried out during the crop cycle, with the applied fungicide being Nativo (Tebuconazole + Trifloxystrobin) at $0.7 \mathrm{~L}$ dose of the commercial product per hectare, and the used insecticides being Engeo Pleno ${ }^{\mathrm{TM}}$ (thiametoxam + lambda-cyhalothrin) and Platinum (thiametoxam + lambda-cyhalothrin), both at the $0.15 \mathrm{~L} / \mathrm{ha}$ dosage of the commercial product.

The topdressing application of nitrogen fertilizer in the treatments in which it the application was predicted was made according to the appropriate agricultural meteorological criteria, whenever the forecast indicated rainfall soon after the cuts.

Grain harvesting was performed when the plants reached approximately $13 \%$ of humidity, in a mechanically wise procedure, with a specific harvester for the plots. 
After harvesting, evaluations were performed regarding yield and technological quality components from the grains. The said evaluations were plant height at harvest, which was obtained by randomly measuring three plants per plot on the harvest day; Thousand grain weight, by weighing three samples of 100 grains with $13 \%$ humidity; Grain yield, where the total harvest of the plot was executed (minus the edges), with the grains later weighed and corrected for hectare and humidity of $13 \%$; And number of spikelets per spike (ear), which was quantified from the count of all spikelets with grains of ten ears.

After harvesting the grains, samples of approximately one kilogram were taken and then sent to the technological quality laboratory from Embrapa Trigo, where the weight of the hectoliter $(\mathrm{WH})$, quantified by specific equipment, was evaluated according to the methodology described in the Seed Analysis Manual by the Ministry of Agriculture, Livestock and Food Supply (Brazil, 1992). The falling number was evaluated using a device called "Hagberg's FallingNumber" following the methodology described in its own manual. The protein content in the grain was analyzed by analysis method 39-10 (AACC, 2000).

\section{Results and Discussion}

During the year which the experiment was developed, there was higher rainfall than the expected for the year, with the exception from the months between July to September where the rainfall was below average for the season, with an accumulated of approximately $274 \mathrm{~mm}$ being observed during this period while the expected was $547 \mathrm{~mm}$, which may have compromised some results.

In data obtained by the statistical analysis, it was possible to notice that for the variables plant height at harvest and grain yield there was interaction between genotypes and cutting regime, with the additional fertilization being significant only for the thousand grain weight (Table 1).

When grain yield was analyzed, the additional $\mathrm{N}$ dose application at the beginning of the earing did not produced significant increases for grain yield. The fact that this fertilization is done late makes that, at this stage, almost all grain yield components are already defined, not being changed even with the $\mathrm{N}$ addition (Pires et al., 2016).

In the cultivars comparison, BRS Pastoreio excelled in grain yield in all cuts when compared to BRS Tarumã, reaching a difference of about $1,300 \mathrm{~kg}$ more when not cut and about
$580 \mathrm{~kg}$ with two cuts, thus showing that it is a more productive cultivar than what was the expected, BRS Tarumã, confirming reports by Castro et al. (2016) (Table 2).

However, with the increase in the cuts number, grain yield decreased for both genotypes, wherein plants that underwent two cuts had lower yield than those that were not cut. This is due to the increasing cut number; since the plant suffers more from defoliation, it ultimately reduces the photoassimilates redistribution, an important element to plants also in the reproductive period (Bortolini et al., 2004).

Studies show that with two cuts, a $20 \%$ reduction in grain yield may occur (Fontaneli et al., 2009), which was true for the BRS Tarumã genotype, with the reduction reaching $18 \%$ when compared two cuts and no cuts. For BRS Pastoreio, this reduction was of almost $30 \%$.

When the apical meristems are removed from the tillers by cutting or grazing, the grain yield is defined by the secondary tillers, which usually originate smaller ears with lower weight grains, causing at the end of the cycle the number of tillers with spikes is altered, affecting the grain yield of these materials (Bortolini et al., 2004).

In relation to the plant height, it was shown that the double-purpose wheat cultivar, BRS Pastoreio, had a height higher than the BRS Tarumã cultivar, by $21 \%$, when not cut, which is close to $16 \mathrm{~cm}$, with the mean height being similar when they received up to two cuts. There was a reduction in plant height from cultivar BRS Pastoreio due to the cuts, but not differing between the cuts ( $1 \mathrm{C}$ and $2 \mathrm{C}$ ), while BRS Tarumã had similar behavior for all cutting regimes (Table 3 ).

Additional nitrogen fertilization did not significantly influence the results regarding the studied plants height. However, when taking into account the genetic diversity of the wheat crop, traits such as plant height are of great importance (Martin et al., 2010).

Table 2. Grain yield ( $\mathrm{kg} \mathrm{ha}^{-1}$ ) of two dual-purpose wheat genotypes in three cutting regimes, in means of two ways of applying additional $\mathrm{N}$ to spike. Passo Fundo, 2017.

\begin{tabular}{ccc}
\hline Treatment & BRS Pastoreio & BRS Tarumã \\
\hline No cut & $4.591 \mathrm{Aa}$ & $3254 \mathrm{Ba}$ \\
One cut & $4.257 \mathrm{Aa}$ & $3091 \mathrm{Bab}$ \\
Two cuts & $3.226 \mathrm{Ab}$ & $2644 \mathrm{Bb}$ \\
\hline
\end{tabular}

Means followed by the same letter, uppercase in the row, and the same lowercase letter in the column, do not differ statistically by the $\mathrm{F}$ and Tukey test at $5 \%$ error probability, respectively.

Table 1. Limit values of the significance level as a percentage by the $F$ test and coefficient of variation for the variables: plant height at harvest, grain yield, number of spikelets ear ${ }^{-1}$, and thousand grain weight (TGW).

\begin{tabular}{|c|c|c|c|c|}
\hline Factors & Plant height at harvest $(\mathrm{cm})$ & Grain yield & Number of spikelets ear ${ }^{-1}$ & TGW (g) \\
\hline Genotypes (GE) & $00.08 *$ & $00.00 *$ & $00.00^{*}$ & $01.20^{*}$ \\
\hline Cuts (CO) & $00.18 *$ & $00.00 *$ & $00.04 *$ & 00.39 * \\
\hline Fertilization (FE) & 30.99 ns & 68.19 ns & $94.60 \mathrm{~ns}$ & $00.78 *$ \\
\hline Int GE x FE & $74.58 \mathrm{~ns}$ & $28.38 \mathrm{~ns}$ & $61.24 \mathrm{~ns}$ & $07.12 \mathrm{~ns}$ \\
\hline Int $\mathrm{CO} \times \mathrm{FE}$ & 96.84 ns & 59.66 ns & $81.51 \mathrm{~ns}$ & $21.21 \mathrm{~ns}$ \\
\hline Int GE x CO x FE & $79.55 \mathrm{~ns}$ & $30.18 \mathrm{~ns}$ & 57.87 ns & $11.59 \mathrm{~ns}$ \\
\hline
\end{tabular}

ns: Not significant; *Significant at $p \leq 0.05$ of probability. 
Table 3. Wheat plant height $(\mathrm{cm})$ at the harvest time, considering two dual-purpose wheat genotypes and three cutting regimes, in the means from two ways of applying additional $\mathrm{N}$ to the ear. Passo Fundo, 2017.

\begin{tabular}{ccc}
\hline Treatment & BRS Pastoreio & BRS Tarumã \\
\hline No cut & $93.7 \mathrm{Aa}$ & $77.5 \mathrm{Ba}$ \\
One cut & $78.3 \mathrm{Ab}$ & $74.6 \mathrm{Aa}$ \\
Two cuts & $78.8 \mathrm{Ab}$ & $75.0 \mathrm{Aa}$ \\
\hline
\end{tabular}

Means followed by the same letter, uppercase in the row, and the same lowercase lette in the column, do not differ statistically by the $\mathrm{F}$ and Tukey test at $5 \%$ error probability respectively. $\mathrm{ns}=$ not significant.

The height of the wheat plant at the end of the cycle was influenced by both genotype and cutting regimes, showing, for example, that the BRS Pastoreio cultivar is characterized by its large size, with mean of about $88 \mathrm{~cm}$ in tests performed by several years and places in studies by Castro et al. (2016). When not submitted to cuts, made in order to obtain more green mass to feed the livestock, this cultivar tends to be higher than what was reported, with approximately $94.0 \mathrm{~cm}$. On the other hand, the BRS Tarumã cultivar did not show large variations in height when it was not submitted to cuts in relation to when they were made.

However, it is normal for a reduction in plant height to occur with the cutting, as occurred with the BRS Pastoreio genotype, which is because the length of the internodes decreases and the tillers end up growing more uniformly, making it so that cutting or grazing act as a natural growth regulator (Fontaneli et al., 2016).

There were differences between cultivars in regarding the number of spikelets/ear, where the BRS Pastoreio cultivar had higher values, about $10 \%$ more, when compared to the other genotype. Another factor observed is the decrease in this number with the increase in the number of cuts, reaching an average difference of two more spikelets/ear when not cut, in relation to the more intense cutting regime (2C) (Figure 1).

The number of spikelets/ear was also influenced only by cutting regime and genotypes. When defoliation was higher due to intensification of cut management, this number decreased, thus showing the influence that the leaf shoot has on yield components (Zilio et al., 2017). By analyzing the cultivars in isolation, it is seen that cultivars that have a higher
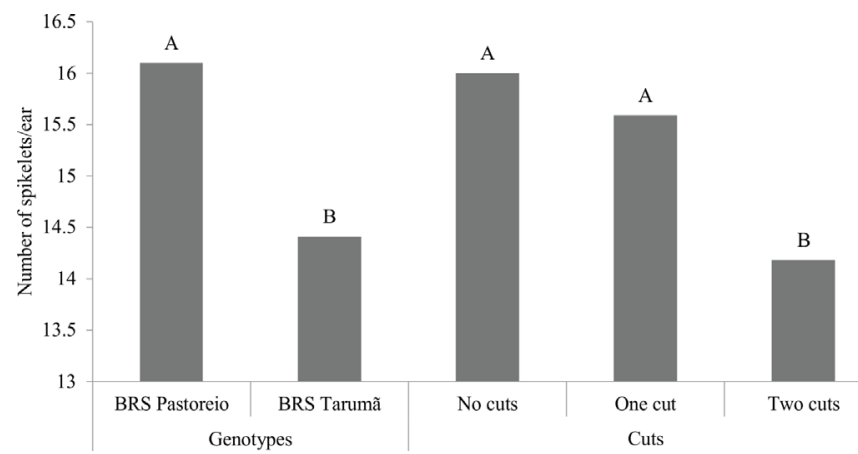

Means followed by the same capital letter in the section do not differ statistically by the Tukey test at $5 \%$ probability of error.

Figure 1. Number of spikelets/ear of two dual-purpose wheat genotypes and three cutting regimes. Passo Fundo, 2017. average grain yield presented higher number of spikelets/ear, as this is a highly correlated attribute with grain yield.

When analyzed the thousand grain weight, the BRS Tarumã cultivar presented about $2 \mathrm{~g}$ more when compared to BRS Pastoreio (Figure 2). This shows that due to the BRS Pastoreio cultivar presenting both higher grain yield and number of spikelets/ear; it should have produced a larger amount of lighter grains.

Regarding the regime of cuts, the weight obtained when two cuts were made was about $2.6 \mathrm{~g}$ lower when compared to just one cut. For the nitrogen fertilization factor, additional nitrogen fertilization at the beginning of the earing reduced the thousand grain weight by $5 \%$ when compared to the situation of not applying this treatment (Figure 2).

The reduction in grain weight with late $\mathrm{N}$ application may have occurred due to the increase in the number of spikelets/ ear, which would consequently increase the number of grains, and thus increasing competition for photoassimilates and nutrients, which ultimately reduces the grain weight.

All factors acted significantly, but in isolation, regarding the thousand grain weight. This value decreased with intensive defoliation (two cuts), mainly due to the fact that making cuts causes the reduction of the tiller survival rate, and with defoliation the reserves are destined for the recovery of leaves and stalks; therefore, the number of spikelets/ear is reduced, causing the grain weight to fall as well (Bortolini et al., 2004).

Genotypes also responded differently to the thousand grain weight, but this difference was already observed in the field in other experiments (Wendt et al., 2006; Castro et al., 2016).

Regarding the grain quality components, the values obtained by the statistical analysis for the grain quality traits are displayed in Table 4.

When additional late nitrogen fertilization was applied, the weight of the BRS Tarumã cultivar was up to $3.5 \%$ higher than the BRS Pastoreio when two cuts were made, similar only to when there were no cuts. With only one cut, the values were

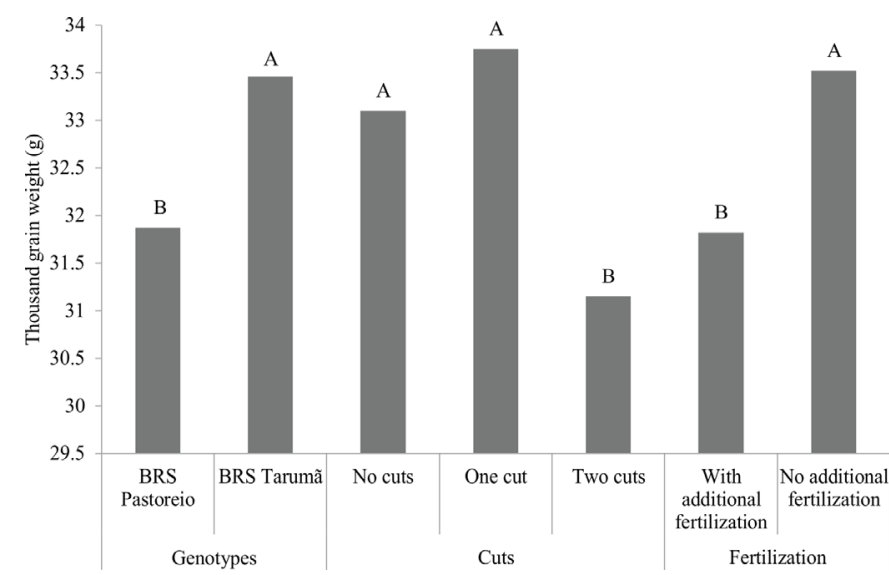

Means followed by the same capital letter in the section do not differ statistically by the Tukey test at $5 \%$ probability of error.

Figure 2. Thousand grain weight of two double-purpose wheat genotypes, three cutting regimes and with application or absence of additional nitrogen fertilization. Passo Fundo, 2017. 
Table 4. Limit values of the significance level in percentage by the $\mathrm{F}$ test and coefficient of variation for the variables hectoliter weight, falling number, protein in the grain. Passo Fundo, 2017.

\begin{tabular}{cccc}
\hline Factors & $\begin{array}{c}\text { Hectoliter weight } \\
(\mathbf{k g} / \mathrm{hl})\end{array}$ & $\begin{array}{c}\text { Falling number } \\
\text { (seconds) }\end{array}$ & $\begin{array}{c}\text { Protein in the grain } \\
\text { (\% of dry base) }\end{array}$ \\
\hline Genotypes (GE) & $00.02^{*}$ & $02.73^{*}$ & $00.00^{*}$ \\
Cuts (CO) & $01.56^{*}$ & $47.29 \mathrm{~ns}$ & $00.00^{*}$ \\
Fertilization (FE) & $16.21 \mathrm{~ns}$ & $00.97^{*}$ & $00.00^{*}$ \\
Int GE x CO & $01.77^{*}$ & $24.62 \mathrm{~ns}$ & $00.0 *^{*}$ \\
Int GE x FE & $18.97 \mathrm{~ns}$ & $03.45^{*}$ & $00.00^{*}$ \\
Int CO x FE & $00.96^{*}$ & $43.23 \mathrm{~ns}$ & $00.00^{*}$ \\
Int GE x CO x FE & $00.87^{*}$ & $09.48 \mathrm{~ns}$ & $00.00^{*}$ \\
CV (\%) & 1.84 & 18.02 & 1.16 \\
\hline
\end{tabular}

ns: Not significant; ${ }^{*}$ Significant at $\mathrm{p} \leq 0.05$ of probability.

intermediate, differing neither from the management without cuts nor from the one where two cuts were made (Table 5).

When applied a late nitrogen fertilization, BRS Tarumã cultivar had higher values in the hectoliter weight only in the no cuts treatment. With one cut, the response was similar in relation to its non-application, but these values reduced when two cuts were made and the additional fertilization was applied.

About the isolated behavior of each cultivar in relation to the application or non-application of additional nitrogen fertilization, BRS Pastoreio was shown as similar in both cases, with or without the application of this additional fertilization at the beginning of the earing.

There is a tendency of dual-purpose materials for, without $\mathrm{N}$ addition, improving $\mathrm{pH}$ when they receive cuts. This is due to the reduction of lodging that occurs with the cutting and consequently results in heavier grains, but only occurring if the grazing intensity and time are not severe (Bortolini et al., 2004). Same situation happened for the BRS Tarumã cultivar, where the highest $\mathrm{pH}$ values occurred when there was no $\mathrm{N}$ addition and the cultivar was submitted to cuts.

On the other hand, the double-purpose oat $\mathrm{pH}$ was reduced when the plants were cut in most genotypes (Scheffer-Basso et al., 2001). This was verified with the BRS Pastoreio cultivar in both fertilization regimes, where its $\mathrm{PH}$ values decreased when submitted to two cuts.

When evaluating the $\mathrm{pH}$, one of the positive factors was that none of the treatments caused the wheat to be classified as out of type $(<72)$. The BRS Tarumã cultivar treatments with additional fertilization and no cuts and one cut, were classified as type 1 (>78), as well as the treatments without this additional fertilization. No cuts BRS Pastoreio, and one and two cuts BRS Tarumã also fell into type 1 classification (Brasil, 2010).

Regarding the falling number, only BRS Tarumã without fertilization had a falling number of less than 250 , with a mean of approximately 221. The reduction in the falling number, which indicates high alpha-amylase enzyme activity, is detrimental to commercialization in Brazil, because it takes this criterion into account (Brazil, 2010). For BRS Pastoreio there were no differences between the application or not of additional nitrogen fertilization, while for BRS Tarumã it had the falling number increased to about $39 \%$ when it was applied from 221 to 308 (Table 6).

These values show that the rainfall occurred at the time of grain harvest did not negatively affect the obtained results.

One of the traits that was of great importance in the analysis of the results was the protein content of the grains, where the BRS Tarumã cultivar showed an increase of approximately $23 \%$ on the mean protein content of the grains, with the additional nitrogen application in the pre-earing stage for all the cutting regimes. This is mainly because the $\mathrm{N}$ absorbed from the inflorescence emission has its main contribution in increasing the grain protein content, and one third of the accumulated nitrogen by the plant during its development is assimilated during the grains filling stage for this purpose (Lamothe, 2006; Rodrigues et al., 2010).

However, for BRS Pastoreio cultivar, the increase of about $15 \%$ with the additional nitrogen application occurred only

Table 6. Falling number (seconds) of two dual-purpose wheat genotypes submitted or not to additional nitrogen fertilization, in the means from three cutting regimes. Passo Fundo, 2017.

\begin{tabular}{ccc}
\hline Treatment & $\begin{array}{c}\text { With additional } \\
\text { fertilization }\end{array}$ & $\begin{array}{c}\text { No additional } \\
\text { fertilization }\end{array}$ \\
\hline BRS Pastoreio & $310.4 \mathrm{Aa}$ & $300.5 \mathrm{Aa}$ \\
BRS Tarumã & $308.5 \mathrm{Aa}$ & $221.4 \mathrm{Bb}$ \\
\hline
\end{tabular}

Means followed by the same letter do not differ statistically by the $F$ test at $5 \%$ probability of error. Capital letters compare whether or not additional nitrogen fertilization is applied within each genotype, and lowercase letters compare the two genotypes with each other.

Table 5. Hectoliter weight $\left(\mathrm{kg} \mathrm{hl}^{-1}\right)$ of two double-purpose wheat genotypes in three cutting regimes, submitted or not to additional nitrogen fertilization. Passo Fundo, 2017.

\begin{tabular}{ccccc}
\hline \multirow{2}{*}{ Treatment } & \multicolumn{2}{c}{ With additional fertilization } & \multicolumn{2}{c}{ No additional fertilization } \\
\cline { 2 - 5 } & BRS Pastoreio & BRS Tarumã & BRS Pastoreio & BRS Tarumã \\
\hline No cut & $77.7 \mathrm{Aa} \alpha$ & $80.7 \mathrm{Aa} \alpha$ & $79.0 \mathrm{Aa} \alpha$ & $76.1 \mathrm{Bb} \beta$ \\
One cut & $75.7 \mathrm{Bab} \alpha$ & $78.3 \mathrm{Aab} \alpha$ & $77.3 \mathrm{Bab} \alpha$ & $80.3 \mathrm{Aa} \alpha$ \\
Two cuts & $74.3 \mathrm{Bb} \alpha$ & $77.0 \mathrm{Ab} \beta$ & $75.3 \mathrm{Bb} \alpha$ & $79.7 \mathrm{Aa} \alpha$ \\
\hline
\end{tabular}

Means followed by the same letter do not differ statistically by Tukey test at $5 \%$ probability of error, uppercase letters in the row compare genotypes within each fertilizer level, and lowercase in the column. Equal Greek letters do not differ by the F test $(p \geq 0.05)$ and compare each genotype within the two fertilizer levels. 
Table 7. Grain protein (\% on dry basis) of two dual-purpose wheat genotypes in three cutting regimes, submitted or not to additional nitrogen fertilization. Passo Fundo, 2017.

\begin{tabular}{ccccc}
\hline \multirow{2}{*}{ Treatment } & \multicolumn{2}{c}{ With additional fertilization } & \multicolumn{2}{c}{ No additional fertilization } \\
\cline { 2 - 5 } & BRS Pastoreio & BRS Tarumã & BRS Pastoreio & BRS Tarumã \\
\hline No cut & $17.1 \mathrm{Aa} \alpha$ & $16.5 \mathrm{Ba} \alpha$ & $14.8 \mathrm{Ac} \beta$ & $11.6 \mathrm{Bc} \beta$ \\
One cut & $12.6 \mathrm{Bc} \beta$ & $14.7 \mathrm{Ac \alpha}$ & $16.8 \mathrm{Aba}$ & $13.5 \mathrm{Ba} \beta$ \\
Two cuts & $14.2 \mathrm{Bb} \beta$ & $15.5 \mathrm{Ab} \alpha$ & $18.0 \mathrm{Aa} \alpha$ & $12.8 \mathrm{Bb} \beta$ \\
\hline
\end{tabular}

Means followed by the same letter do not differ statistically by Tukey test at $5 \%$ probability of error, uppercase letters in the row compare genotypes within each fertilizer level, lowercase in the column. Equal Greek letters do not differ from each other by the F Test $(p \geq 0.05)$ and compare each genotype within the two fertilizer levels.

when there were no cuts. Regarding the protein content in each cultivar, BRS Tarumã, when applied additional fertilization, was higher than BRS Pastoreio when cuts were made. Yet, when the application did not occur, it was lower than BRS Pastoreio in all cutting regimes (Table 7).

For the BRS Pastoreio cultivar, the highest protein content was found when it was submitted to two cuts and without the $\mathrm{N}$ addition, attaining values of around $18 \%$, with the Pastoreio cultivar mean protein content being $13.2 \%$, according to studies by Castro et al. (2016). This shows that genotypes present differences in their response to this fertilization and in relation to the mean protein levels, since the BRS Tarumã cultivar has commonly presented about $17.7 \%$ protein in other studies (Paiano et al., 2014). For this study, the maximum mean contents were of about $16.5 \%$.

The amount of protein produced in the grain is influenced by nutritional factors, and nitrogen fertilization is considered part of the main ones. This amount also varies according to the used species, and variations may occur within the same species (Rodrigues et al., 2010). Protein accumulation in grains is also influenced by weather conditions during the crop cycle (Dupont et al., 2006; Chope et al., 2014).

Wheat grains protein content has been shown to increase with a later nitrogen application (Yano et al., 2005), and applications during the emergence stage of the ears, for example, have shown a positive effect on nitrogen protein increment in wheat grains (Garrido-Lestache et al., 2004; Fuertes-Mendizábal et al., 2010).

$\mathrm{N}$ application at unusual (late) stages increases protein content in grains, especially when soil $\mathrm{N}$ content is low at this stage; nevertheless, it is not enough to change these commercial grade materials (Pires et al. al., 2016).

Additional nitrogen application at the beginning stage of earing had no significant influence on the grain yield traits, and its application to these wheat species is not indicated when aiming only this attribute. Regarding quality, BRS Tarumã cultivar has shown to respond better to this application than BRS Pastoreio, where it only showed improvements when not submitted to cuts, which does not normally happen for this type of material, since its destination is for livestock feed, and not only for grains protein.

\section{Conclusion}

Additional application of nitrogen at the beginning of the earing in dual-purpose wheat did not increase grain yield for any of the studied genotypes (BRS Pastoreio, BRS Tarumã) in any of the cutting regimes.
Regarding grain quality, the analyzed genotypes behaved differently in relation to this $\mathrm{N}$ addition, considering both the used materials and which purpose they want to use grain production for when performing this additional $\mathrm{N}$ application.

\section{Literature Cited}

Almeida, D.; Bredemeier, C.; Variani, C.; Tonon, A. R.; Souza, C. H. L.; Perin, J. Produtividade e qualidade de grãos de trigo em função da aplicação de nitrogênio no florescimento. In: Reunião da Comissão Brasileira de Pesquisa de Trigo e Triticale, 5, 2011, Dourados. Anais... Dourados: Embrapa Agropecuária Oeste, 2011.

American Association of Cereal Chemists - AACC. Approved methods of AACC. 10.ed. Saint Paul: AACC, 2000.

Bortolini, P. C.; Moraes, A.; Veiga, M.; Pelissarim, A.; Dieckow, J. Cereais de inverno submetidos ao corte no sistema duplo propósito. Revista Brasileira de Zootecnia, v.33, n.1, p.45-50, 2004. https://doi.org/10.1590/S1516-35982004000100007.

Brasil. Ministério da Agricultura e Reforma Agrária. Secretaria Nacional de Defesa Agropecuária. Regras de análises para sementes. Brasília: MAPA, 1992. 365p.

Brasil. Ministério da Agricultura, Pecuária e Abastecimento. Instrução normativa no 38, de 30 de novembro de 2010. Estabelece o Regulamento Técnico do Trigo, definindo o seu padrão oficial de classificação, com os requisitos de identidade e qualidade, a amostragem, o modo de apresentação e a marcação ou rotulagem, nos aspectos referentes à classificação do produto. Diário Oficial da União, v.147, n.229, seção 1, p. 2-4, 2010.

Bredemeier, C.; Mundstock, C. M. Estádios fenológicos do trigo para a adubação nitrogenada em cobertura. Revista Brasileira de Ciência do Solo, v. 25, n. 2, p. 317-323, 2001. https://doi. org/10.1590/S0100-06832001000200008.

Calderini, D. F.; Abeledo, L. G.; Savin, R.; Slafer, G. A. Final grain weight in wheat as affected by short periods of high temperature during pre- and pos-anthesis under field conditions. Australian Journal of Plant Physiology, v. 26, p. 453-458, 1999. https://www. researchgate.net/publication/262960886. 5 No. 2018.

Castro, R. L.; Caierão, E.; Fontaneli, R. S.; Santos, H. P.; Silva, M.S.; Scheeren, P. L.; Guarienti, E. M.; Miranda, M. Z.; Eichelberger, L.; Kopp, M. M.; Nascimento Junior, A.; Lau, D.; Santana, F. M.; Cunha, G. R.; Pires, J. L. F.; Silva Junior, J. P.; Costamilan, L. M.; Lima, M. I. P. M.; Medeiros, C. M. O.; David, D. B.; Conterato, I. F.; Toigo, M. C.; Aires, R. F.; Lannes, S. D.; Garrafa, M; Santos, F. M. BRS Pastoreio: nova cultivar de trigo duplo propósito da Embrapa In: Reunião da Comissão Brasileira de Pesquisa de Trigo e Triticale, 10., 2016, Londrina. Anais... Londrina: Comissão Brasileira de Pesquisa de Trigo e Triticale, 2016. 242p. 
Chope, G, A.; Wan, Y.; Penson, S. P.; Bhandari, D. G.; Poderes, S. J.; Shewry, P. R.; Hawkesford, M. J. Effects of genotype, season, and nitrogen nutrition on gene expression and protein accumulation in wheat grain. Journal of Agricultural and Food Chemistry, v. 62, n. 19, p. 4399-4407, 2014. https://doi.org/10.1021/jf500625c.

Dupont, F. M.; Hurkman W. J.; Vensel W. H, Tanaka C.; Kothari K. M.; Chung O. K.; Altenbach, S. B. Protein accumulation and composition in wheat grains: Effects of mineral nutrients and high temperature. European Journal of Agronomy, v. 25, n. 2, p. 96-107, 2006. https://doi.org/10.1016/j.eja.2006.04.003.

Fontaneli, R. S.; Santos, H. P.; Caierão, E.; Castro, R. L.; De Mori, C. O trigo na integração lavoura pecuária. In: De Mori, C.; Antunes, J. M.; Fae, G. S.; Acosta, A. S. (Eds.). Trigo: o produtor pergunta, a Embrapa responde. Brasília: Embrapa, 2016. p. 215-228.

Fontaneli, R. S.; Santos, H. P.; Fontaneli, R. S.; Del Duca, L. J.; Rodrigues, O.; Teixeira, M. C. C.; Nascimento Junior, A.; Minella, E.; Caierão, E.; De Mori, C.; Oliveira, J. T.; Mariani, F. Potencial de rendimento de cereais de inverno de duplo propósito. In: Fontaneli, R. S.; Santos, H. P.; Fontaneli, R. S. (Eds.). Forrageiras para integração lavoura-pecuária-floresta na região sul-brasileira. Passo Fundo: Embrapa Trigo, 2009. p. 97-120.

Fuertes-Mendizábal, T., Aizpurua, A.; González-Maro, M. B.; Estavillo, J. M. Improving wheat breadmaking quality by splitting the $\mathrm{N}$ fertilizer rate. European Journal of Agronomy, v. 33, n.1, p. 52-61, 2010. https://doi.org/10.1016/j.eja.2010.03.001.

Garrido-Lestache, E.; López-Bellido, R.; López-Bellido, L. Effect of N rate, timing and splitting and $\mathrm{N}$ type on bread-making quality in hard red spring wheat under rainfed Mediterranean conditions. Field Crops Research, v. 85, n. 2-3, p. 213-236, 2004. https://doi. org/10.1016/S0378-4290(03)00167-9.

Lamothe, A. G. Trigo: calidad vs. rendimiento. In: INIA (Ed.) Jornada técnica de cultivos de invierno. Montevideo: CIMMYT/INIA, 2006. p. 207-246. (Serie de Actividades de Difusión, 444).

Large, E. C. Growth stages in cereals illustration of the Feeks scales. Plant Pathology, v.3, n.4, p. 22-24, 1954. https://doi. org/10.1111/j.1365-3059.1954.tb00716.x.

Martin T. N.; Simionatto C. C.; Bertoncelli P.; Ortiz M. H.; Ziech M. F.; Soares, A. B. Phytomorphology and production of dual purposes wheat with different cutting regimes and seeding density. Ciência Rural, v. 40, n. 8, p. 1695-1701. 2010. https://doi.org/10.1590/ S0103-84782010000800004.
Paiano, D.; Nantes, C. L.; Krahl, G.; Tubin, J. S. B.; Conte, R. A.; Dal Pivo, J. C.; Ferraz, S. M.; Baretta, D. Digestibilidade do grão de trigo de duplo propósito, cultivar BRS Tarumã, produzido em sistema agroecológico ou convencional para suínos. Semina: Ciências Agrárias, v. 35, n. 4, suplemento, p. 2767-2778, 2014. https://doi.org/10.5433/1679-0359.2014v35n4Suplp2767.

Pires, J. L. F.; Strieder, M. L.; Santos, H. P.; De Bona, F. D. Semeadura, práticas de manejo e adubação nitrogenada em cobertura. In: De Mori, C.; Antunes, J. M.; Fae, G. S.; Acosta, A. S. (Eds.). Trigo: o produtor pergunta, a Embrapa responde. Brasília: Embrapa, 2016. p. 215-228.

Rodrigues, O.; Didonet, A. D.; Teixeira, M. C. C. Potencial de rendimento de grãos. In: Rodrigues, O.; Teixeira, M. C. C. (Eds.). Bases ecofisiológicas para manutenção da qualidade do trigo. Passo Fundo: Embrapa Trigo, 2010. p.47-63.

Sangoi, L.; Berns, A. C.; Almeida, M. L.; Zanin, C. G.; Schweitzer, C. Características agronômicas de cultivares de trigo em resposta à época da adubação nitrogenada de cobertura. Ciência Rural, v. 37, n.6, p. 1564-1570, 2007. https://doi.org/10.1590/S010384782007000600010 .

Scheffer-Basso, S. M.; Floss, E. L.; Cechetti, D.; Baréa, K.; Bortolini, F. Potencial de Genótipos de Aveia para Duplo Propósito. Revista Brasileira de Agrociência, v. 7 n. 1, p. 22-28, 2001. https://doi. org/10.18539/cast.v7i1.369.

Vieira, R. D.; Fornasieri Filho, D.; Minohara, L.; Bergamaschi, M. C. $M$. Efeito de doses e de épocas de aplicação de nitrogênio em cobertura na produção e na qualidade fisiológica de sementes de trigo. Científica, v.23, n.2, p.257-264, 1995.

Wendt, W.; Del Duca, L. J. L.; Caetano, V. R. Avaliação de cultivares de trigo de duplo propósito, recomendados para cultivo no estado do Rio Grande do Sul. Pelotas: Embrapa Clima Temperado, 2006. 2p. (Embrapa Clima Temperado. Comunicado Técnico, 137).

Yano, G. T.; Takahashi, H. W.; Watanabe, T. S. Avaliação de fontes de nitrogênio e épocas de aplicação em cobertura para o cultivo do trigo. Semina: Ciências Agrárias, v. 26, n. 2, p. 141-148, 2005. https://doi.org/10.5433/1679-0359.2005v26n2p141.

Zilio, M.; Peloso, J. A.; Mantovani, A. Produção de forragem e de grãos de trigo de duplo propósito submetido a diferentes densidades de semeadura, adubação nitrogenada e manejos de corte. Revista de Ciências Agroveterinárias, v.16, n.4, p.367-375, 2017. https://doi.org/10.5965/223811711642017367. 